\title{
Genotypic characterization of lactic acid bacteria isolated from traditional Pecorino Siciliano cheese
}

\author{
Anna VernILE ${ }^{1 *}$, Giovanni GIAMMANCO ${ }^{2}$, Giuseppe SPANO $^{1}$, \\ Thomas P. BERESFORD ${ }^{3}$, Patrick F. FoX ${ }^{4}$, Salvatore MASSA ${ }^{1}$ \\ ${ }^{1}$ Department of Food Science, Agricultural Faculty of Foggia, University of Foggia, via Napoli 25, \\ 71100 Foggia, Italy \\ ${ }^{2}$ Department of Hygiene and Microbiology, University of Palermo, via del Vespro, 133, \\ 90127 Palermo, Italy \\ ${ }^{3}$ DPRC, Moorepark, Teagasc, Fermoy, Co. Cork, Ireland \\ ${ }^{4}$ University College Cork, Department of Food and Nutritional Sciences, Co. Cork, Ireland
}

Received 12 November 2007 - Accepted 18 April 2008

\begin{abstract}
A total of 468 lactic acid bacteria (LAB) isolates from the interior of six traditional Pecorino Siciliano cheeses during ripening (1,30 and 90 days) were characterized genotypically in order to assess the biodiversity within this wild microbial population. Two DNA-based technique, PCR and PFGE were used for genetic typing of isolates. Of the 468 isolates, species-specific PCR analysis showed that 79, 58, 2, 9 and 4 isolates reacted with primers for Lactobacillus paracasei, Lb. plantarum, Lb. pentosus, Lb. rhamnosus and Lb. curvatus, respectively and no isolates reacted with the $L b$. casei primers. Genus-specific PCR analysis showed that 59 isolates reacted positively with the lactococcal primers, 221 with the enterococcal primers and 34 with the Leuconostoc primers, 1 with the pediococcal primers and 4 with the streptococcal primers. Enterococci were characterized at species level and twelve of the 221 enterococci isolates showed positive reaction with the E. faecalis species-specific primers, and the remainder 209 isolates positively with the E. faecium species-specific primers. PFGE analysis allowed to identify different strains of the same species of $L b$. plantarum and $L b$. paracasei. The strains which reacted positively with $L b$. curvatus, Lb. pentosus or Lb. rhamnosus primers gave a unique PFGE pattern. PFGE indicated 52 different band patterns for enterococci, 9 for lactococci, 5 for leuconostocs and 1 for streptococci and pediococci. The results suggest that wild bacterial populations should be preserved in order to protect the traditional raw milk cheeses, and to select new specific strains for the dairy industry.
\end{abstract}

Pecorino cheese / microbiological analysis / PCR / PFGE

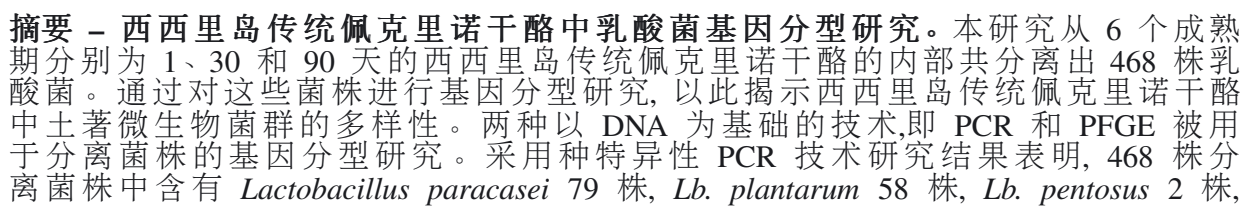

*Corresponding author (通讯作者): a.vernile@unifg.it 
Lb. rhamnosus 9 株, Lb. curvatus 4 株, 未发现 Lb. casei 菌。属特异性 PCR 分析表明, 有 59 株乳酸菌属于乳球菌属, 221 株乳酸菌属于肠球菌属, 34 株乳酸菌属于明串珠菌属, 1 株乳 酸菌属于片球菌属, 4 株乳酸菌株属于链球菌属。利用种特异性引物分析对 221 株肠球菌 属的乳酸菌进行分析, 结果表明, 其中 12 株菌为 E. faecalis, 其余 209 株菌为 E. faecium。 利用 PFGE 方法, 进一步确定了 Lb. plantarum 和 Lb. paracasei 相同菌种的不同菌株。与 Lb. curvatus、Lb. pentosus、Lb. rhamnosus 的种特异性引物有阳性反应的菌株, 均呈现一个 独特的 PFGE 图谱。经 PFGE 分析, 分离获得的肠球菌属、乳球菌属、明串珠菌属、链球菌

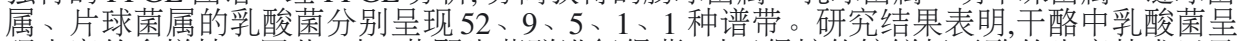
现丰富的多样性。因此, 对一些野生菌群进行保藏, 对于保护传统鲜奶干酪的生产技术以及 为乳品工业选择一些特殊的菌种是非常有必要。

\section{佩克里诺干酪 / 微生物分析 / PCR / PFGE}

Résumé - Caractérisation génotypique de bactéries lactiques isolées de fromage traditionnel Pecorino Siciliano. La caractérisation génotypique de 468 isolats de bactéries lactiques provenant de l'intérieur de six fromages traditionnels Pecorino Siciliano en cours d'affinage (1,30 et 90 jours) a permis d'évaluer la biodiversité de cette population microbienne sauvage. Deux techniques basées sur l'ADN, la PCR et la PFGE, ont été utilisées pour typer les isolats. Parmi les 468 isolats, l'analyse par PCR spécifique de l'espèce a montré que 79, 58, 2, 9 et 4 isolats correspondaient aux amorces respectives de Lactobacillus paracasei, Lb. plantarum, Lb. pentosus, Lb. rhamnosus et Lb. curvatus. Aucun isolat ne correspondait à $L b$. casei. L'analyse par PCR spécifique du genre a montré que 59 isolats correspondaient aux amorces des lactocoques, 221 à celles des entérocoques, 34 à celles des leuconostocs, 1 à celles des pédiocoques et 4 à celles des streptocoques. Parmi les 221 isolats d'entérocoques, 12 correspondaient aux amorces spécifiques de l'espèce Enterococcus faecalis, et les 209 isolats restants à celles de E. faecium. L'analyse par PFGE a permis d'identifier différentes souches au sein des espèces $L b$. plantarum et $L b$. paracasei. Les souches qui correspondaient aux amorces de Lb. curvatus, Lb. pentosus ou Lb. rhamnosus ont généré un unique profil de restriction par PFGE. La PFGE a généré 52 profils de restriction différents pour les entérocoques, 9 pour les lactocoques, 4 pour les leuconostocs et 1 pour les streptocoques et pédiocoques. Les résultats suggèrent que les populations bactériennes sauvages devraient être préservées afin de protéger les fromages traditionnels au lait cru, et de sélectionner de nouvelles souches de levains pour l'industrie laitière.

\section{fromage Pecorino / analyse microbiologique / PCR / PFGE}

\section{INTRODUCTION}

"Protected Designation of Origin" (PDO) status was awarded in 1955, for Pecorino Siciliano cheese. The evolution of dairy microflora is of particular interest for the PDO cheeses because these kind of cheeses are often made with raw milk containing a large number of adventitious micro-organisms.

Pecorino Siciliano is a raw ewe's milk cheese made by a traditional method. The raw milk was heated to $35-37{ }^{\circ} \mathrm{C}$ and rennet paste $\left(0.682 \mathrm{~g} \cdot \mathrm{L}^{-1}\right)$ was added. Coagulation was allowed to proceed for 45-60 min, after which the coagulum was cut into pea-sized pieces, and covered slowly with water at $70{ }^{\circ} \mathrm{C}$, to facilitate the release of whey. Immediately after separa- tion of the whey, the curds, without being mixed, were transferred to a woven basket and warmed with "scotta" (whey at $80^{\circ} \mathrm{C}$ ) for $2-3 \mathrm{~h}$ to about $40{ }^{\circ} \mathrm{C}$, after which they were held at room temperature for $24 \mathrm{~h}$. The following day, the cheese is salted on the surface or washed with saturated brine. The cheese was then left to ripen for $90 \mathrm{~d}$ at about $10-15{ }^{\circ} \mathrm{C}$.

The importance of raw milk as a source of strains harbouring genetic diversity has been outlined in the traditional cheeses produced without pasteurization [12]. The study of the microflora present in the cheese and its evolution throughout the ripening are important for establishing the bacterial groups responsible for the characteristic flavour of this kind of cheese 
and for the isolation of new strains for the dairy industry. Lactic acid bacteria play a significant role in cheese ripening by virtue of their ability to autolyse and release intracellular peptidases into the cheese matrix.

Changes in the microflora occurring during ripening have been studied by means of classical identification, such as phenotypic tests, and genotypic methods. Phenotypic methods are those that detect characteristic that are expressed by the microorganisms, but these methods involve some problems such as the non reproducibility and lack of discriminatory power. Genotypic methods have been developed to get over the disadvantages of the traditional phenotypic methods. In the last few years, the development of new methods involving various DNA-based typing techniques [21] has opened up new perspectives for examining microbial communities of traditional or industrial Italian cheeses [13, 20, 28, 32, 34]. Pulsed field gel electrophoresis (PFGE) analysis, in this study, was used as a tool for examining overall genome similarity or divergence among strains.

Few studies are available on the autochthonous microflora of traditional Pecorino Siciliano cheese [35]. The aim of this work was to characterize the lactic acid bacteria isolated from Pecorino Siciliano cheese on the basis of phenotypic and genotypic features in order to assess the biodiversity within this wild microbial population. Typing methods based on molecular techniques (PCR and PFGE) have been used for the identification of the isolates to study the dynamics of bacterial population in the cheese.

\section{MATERIALS AND METHODS}

\subsection{Bacterial strains and phenotypic characterization}

Six samples of Pecorino Siciliano cheese made by the same producer in the neighbourhood of Ragusa (Sicily), at different stages of ripening (1, 30 and $90 \mathrm{~d}$ ) were studied.

A $20 \mathrm{~g}$ sample from the interior of each cheese was taken aseptically and added to $180 \mathrm{~mL}$ of sterile Maximum Recovery Diluent and homogenized using a stomacher for $5 \mathrm{~min}$. Serial dilutions were made in the same diluent. Appropriate dilutions of samples from the interior of the cheeses were analysed by the pour-plate technique for the isolation of: putative lactococci on LM17 (Oxoid, Basingstoke, UK) incubated at $30{ }^{\circ} \mathrm{C}$ for $3 \mathrm{~d}$; streptococci on LM17 (Oxoid) incubated under anaerobic conditions at $45{ }^{\circ} \mathrm{C}$ for $3 \mathrm{~d}$; enterococci on KAA agar (Oxoid) incubated at $37{ }^{\circ} \mathrm{C}$ for $1 \mathrm{~d}$, mesophilic lactobacilli on Rogosa agar (Oxoid) incubated with an overlay at $30{ }^{\circ} \mathrm{C}$ for $5 \mathrm{~d}$, or on MRS (Oxoid) containing $\left(30 \mathrm{mg} \cdot \mathrm{L}^{-1}\right)$ vancomycin (Sigma, St. Louis, USA), at $30{ }^{\circ} \mathrm{C}$ for $5 \mathrm{~d}$ under anaerobic conditions. The spread-plate technique was used also to isolate putative thermophilic lactobacilli on MRS (Oxoid) $\mathrm{pH} 5.4$ incubated at $45^{\circ} \mathrm{C}$ for $3 \mathrm{~d}$ under anaerobic conditions.

Isolated colonies ( 8 or 9 colonies) were selected from countable plates of Rogosa, MRS at $30{ }^{\circ} \mathrm{C}$ or $45{ }^{\circ} \mathrm{C}$, LM17 at $30{ }^{\circ} \mathrm{C}$ or $45^{\circ} \mathrm{C}$, and KAA. Cellular morphology was confirmed by microscopic examination and isolates were re-streaked on their respective media and incubation conditions to obtain pure cultures. Pure cultures were maintained as frozen stocks at $-20{ }^{\circ} \mathrm{C}$ in a 1:1 glycerol-MRS or glycerol-LM17 mixture until phenotypic and genotypic characterisation of isolates was undertaken.

Prior to phenotypic characterization, stock cultures were activated by plating on either MRS or LM17 agar. Single colonies were subsequently selected and tested for the production of catalase using $\mathrm{H}_{2} \mathrm{O}_{2}$ (30 $\mathrm{mL} \cdot \mathrm{L}^{-1}$ ) and their Gram reaction by staining followed by microscopic examination. 
A total of 468 isolates the plates with a number of colony-forming units (cfu) ranging from 10 to 300 were selected for isolation from six samples of Pecorino Siciliano cheeses, at different stages of ripening (1, 30 and $90 \mathrm{~d})$ were analysed.

Ability to grow at 10,30 or $45^{\circ} \mathrm{C}$ and in the presence of $6.5 \% \mathrm{NaCl}$ at $30{ }^{\circ} \mathrm{C}$ was used as phenotypic tests for coccalshaped cells, while growth at 15 or $45^{\circ} \mathrm{C}$, production of $\mathrm{CO}_{2}$ and hydrolysis of arginine were used for the rod-shaped cells; growth was assayed by visual observation. Coccal-shaped cells from a fresh culture were grown in $5 \mathrm{~mL} \mathrm{LM} 17$ broth (2\% inoculum). Growth was determined after incubation at $10{ }^{\circ} \mathrm{C}$ for $7 \mathrm{~d}$, at 30 or $45{ }^{\circ} \mathrm{C}$ for $2 \mathrm{~d}$ and in LM17 broth containing $6.5 \%$ $\mathrm{NaCl}$ for $3 \mathrm{~d}$. Rod-shaped cells from a $2 \%$ inoculum prepared from a fresh culture were grown in MRS broth. Growth at $15^{\circ} \mathrm{C}$ or $45^{\circ} \mathrm{C}$ was determined following incubation for 5 or $2 \mathrm{~d}$, respectively. The ability of the isolates to produce $\mathrm{CO}_{2}$ from glucose was determined in tubes containing $5 \mathrm{~mL}$ MRS, from which the citrate was omitted and inverted Durham tube. The test tubes were observed for the production of gas in the Durham tube after 2 and $5 \mathrm{~d}$ at the temperature at which the strains were isolated. The ability to produce $\mathrm{NH}_{3}$ from arginine was measured in Abd-El-Malek medium containing $5 \mathrm{~g}$ tryptone, $2.5 \mathrm{~g}$ yeast extract, $0.5 \mathrm{~g}$ glucose, $2 \mathrm{~g} \mathrm{~K} \mathrm{~K}_{2} \mathrm{HPO}_{4}, 3 \mathrm{~g}$ L-arginine monohydrochloride per liter of distilled water. The tubes containing $5 \mathrm{~mL}$ of the medium with $2 \%$ inoculum were observed after $4 \mathrm{~d}$ at the same temperature at which the strains were isolated and the assay for the presence of $\mathrm{NH}_{3}$ was carried out by the addition of Nessler's reagent to the tubes. A colour change from yellowish to orange indicates the production of $\mathrm{NH}_{3}$ from arginine. On the basis of these phenotypic tests, the isolates were presumptively classified at genus level.

\subsection{PCR analysis}

Genomic DNA was extracted from overnight cultures using the procedure of Coakley et al. [9]. The final concentration of DNA was estimated using agarose gel electrophoresis and ethidium bromide staining.

PCR of presumptive strains of Enterococcus, Lactococcus, Streptococcus, Pediococcus, Leuconostoc and Lactobacillus genera was performed in a DNA Thermal Cycler (Perkin Elmer, Cheshire, UK). Streptococci, pediococci, leuconostoc and lactococci were characterized to genus level, while lactobacilli and enterococci were characterized to species level. The primer sequences and the PCR amplification conditions applied are shown in Table I.

A 100-bp ladder (Pharmacia Biotech, San Francisco, USA) was run along-side the samples as a molecular weight marker. The gels were run for $2 \mathrm{~h}$ at $110 \mathrm{~V}$ and the DNA visualized by UV transillumination.

\subsection{PFGE}

Pulsed field gel electrophoresis was performed as described previously by Brennan et al. [4]. The restriction enzymes used were $A s c \mathrm{I}$ (New England BioLabs, Hertfordshire, UK) and ApaI (New England BioLabs) for the rod-shaped cells and coccal-shaped cells, respectively.

Gels with DNA from rod-shaped cells were run at $6.0 \mathrm{~V}$ for $20 \mathrm{~h}$ at $14{ }^{\circ} \mathrm{C}$, with the pulse time ramped from 1 and $30 \mathrm{~s}$. The DNA from coccal-shaped cells was run under the same conditions for $16 \mathrm{~h}$, but with the pulse time ramped from 5 to $30 \mathrm{~s}$. The agarose gels were stained with ethidium bromide $\left(0.5 \mu \mathrm{g} \cdot \mathrm{mL}^{-1}\right.$ in distilled water), destained in distilled water, visualized under UV lights and photographed using Polaroid type 667 film (Sigma).

The TIFF images were searched for lanes and bands using the RestrictoScan 
Table I. Primers and amplification conditions for detection of coccal- and rod-shaped cells.

\begin{tabular}{|c|c|c|c|}
\hline Primer sequences & Amplification conditions & $\begin{array}{l}\text { Predicted } \\
\quad \text { PCR } \\
\text { product size }\end{array}$ & $\begin{array}{c}\text { Primer } \\
\text { specificity } \\
\text { and reference }\end{array}$ \\
\hline $\begin{array}{l}\text { 5'-AAC TCT GTT GTT AGA G-3' } \\
\text { 5'-ATC TCT AGG AAT AGC AC-3' }\end{array}$ & $\begin{array}{l}5 \text { min at } 94{ }^{\circ} \mathrm{C}, 25 \text { cycles of: } \\
1 \text { min at } 94{ }^{\circ} \mathrm{C}, 1 \mathrm{~min} \text { at } 55{ }^{\circ} \mathrm{C} \text {, } \\
1 \mathrm{~min} \text { at } 72{ }^{\circ} \mathrm{C}\end{array}$ & 570 & $\begin{array}{l}\text { Lactococcus } \\
\text { Deasy et al. [16] }\end{array}$ \\
\hline $\begin{array}{l}\text { 5'-TCA ACC GGG GAG GGT-3' } \\
\text { 5'-ATT ACT AGC GAT TCC GG-3' }\end{array}$ & $\begin{array}{l}5 \text { min at } 94{ }^{\circ} \mathrm{C}, 25 \text { cycles of: } \\
1 \text { min at } 94{ }^{\circ} \mathrm{C}, 1 \mathrm{~min} \text { at } 60^{\circ} \mathrm{C} \text {, } \\
1 \mathrm{~min} \text { at } 72{ }^{\circ} \mathrm{C}\end{array}$ & 733 & $\begin{array}{l}\text { Enterococcus } \\
\text { Deasy et al. [16] }\end{array}$ \\
\hline $\begin{array}{l}\text { 5'-CCA CAG CGA AAG GTG CTT GCA C-3' } \\
\text { 5'-GAT CCA TCT CTA GGT GAC GCC CG-3' }\end{array}$ & $\begin{array}{l}5 \text { min at } 94{ }^{\circ} \mathrm{C}, 25 \text { cycles of: } \\
1 \text { min at } 94{ }^{\circ} \mathrm{C}, 1 \mathrm{~min} \text { at } 55^{\circ} \mathrm{C} \text {, } \\
1 \mathrm{~min} \text { at } 72{ }^{\circ} \mathrm{C}\end{array}$ & 175 & $\begin{array}{l}\text { Leuconostoc } \\
\text { Nissen et al. [31] }\end{array}$ \\
\hline $\begin{array}{l}\text { 5'-AAA CCG ACA CAG GTA G-3' } \\
\text { 5'-CGA TAG GGA TAA CCT A-3' }\end{array}$ & $\begin{array}{l}5 \text { min at } 94{ }^{\circ} \mathrm{C}, 25 \text { cycles of: } \\
1 \text { min at } 94^{\circ} \mathrm{C}, 1 \mathrm{~min} \text { at } 60^{\circ} \mathrm{C} \text {, } \\
1 \text { min at } 72{ }^{\circ} \mathrm{C}\end{array}$ & 588 & $\begin{array}{l}\text { Streptococcus } \\
\text { Deasy [15] }\end{array}$ \\
\hline $\begin{array}{l}\text { 5'-ACT GAT TGA GAT TTT-3' } \\
\text { 5'-TGG CTT TCT GGT TAA-3' }\end{array}$ & $\begin{array}{l}5 \text { min at } 94{ }^{\circ} \mathrm{C}, 25 \text { cycles of: } \\
1 \text { min at } 94^{\circ} \mathrm{C}, 1 \mathrm{~min} \text { at } 55^{\circ} \mathrm{C} \text {, } \\
1 \text { min at } 72{ }^{\circ} \mathrm{C}\end{array}$ & 439 & $\begin{array}{l}\text { Pediococcus } \\
\text { Deasy [15] }\end{array}$ \\
\hline $\begin{array}{l}\text { 5'-CCC ACT GCT GCC TCC CGT AGG AGT-3' } \\
\text { 5'-TGC ACT GAG ATT CGA CTT AA-3' }\end{array}$ & $\begin{array}{l}5 \text { min at } 94{ }^{\circ} \mathrm{C}, 25 \text { cycles of: } \\
1 \text { min at } 94^{\circ} \mathrm{C}, 1 \text { min at } 58{ }^{\circ} \mathrm{C} \text {, } \\
1 \text { min at } 72^{\circ} \mathrm{C}\end{array}$ & 290 & $\begin{array}{l}\text { Lb. casei } \\
\text { Ward and } \\
\text { Timmins [40] }\end{array}$ \\
\hline $\begin{array}{l}\text { 5'-CCC ACT GCT GCC TCC CGT AGG AGT-3' } \\
\text { 5'-CAC CGA GAT TCA ACA TGG-3' }\end{array}$ & $\begin{array}{l}5 \text { min at } 94{ }^{\circ} \mathrm{C}, 25 \text { cycles of: } \\
1 \text { min at } 94^{\circ} \mathrm{C}, 1 \text { min at } 58{ }^{\circ} \mathrm{C} \text {, } \\
1 \text { min at } 72^{\circ} \mathrm{C}\end{array}$ & 290 & $\begin{array}{l}\text { Lb. paracasei } \\
\text { Ward and } \\
\text { Timmins }[40]\end{array}$ \\
\hline $\begin{array}{l}\text { 5'-CCG TTT ATG CGG AAC ACC TA-3' } \\
\text { 5'-TCG GGA TTA CCA AAC ATC AC-3' }\end{array}$ & $\begin{array}{l}5 \text { min at } 94{ }^{\circ} \mathrm{C}, 25 \text { cycles of: } \\
1 \text { min at } 94^{\circ} \mathrm{C}, 1 \text { min at } 58{ }^{\circ} \mathrm{C} \text {, } \\
1 \text { min at } 72{ }^{\circ} \mathrm{C}\end{array}$ & 318 & $\begin{array}{l}\text { Lb. plantarum } \\
\text { Quere et al. [33] }\end{array}$ \\
\hline $\begin{array}{l}\text { 5'-GCT GGA TCA CCT CCT TTC-3' } \\
\text { 5'-TTG GTA CTA TTT AAT TCT TAG-3' }\end{array}$ & $\begin{array}{l}5 \text { min at } 94{ }^{\circ} \mathrm{C}, 25 \text { cycles of: } \\
1 \text { min at } 94^{\circ} \mathrm{C}, 1 \text { min at } 58{ }^{\circ} \mathrm{C} \text {, } \\
1 \text { min at } 72^{\circ} \mathrm{C}\end{array}$ & 200 & $\begin{array}{l}\text { Lb. curvatus } \\
\text { Berthier and } \\
\text { Ehrlich [3] }\end{array}$ \\
\hline $\begin{array}{l}\text { 5'-CCC ACT GCT GCC TCC CGT AGG AGT-3' } \\
\text { 5'-TGC ATC TTG ATT TAA TTT TG-3' }\end{array}$ & $\begin{array}{l}5 \text { min at } 94{ }^{\circ} \mathrm{C}, 25 \text { cycles of: } \\
1 \text { min at } 94^{\circ} \mathrm{C}, 1 \mathrm{~min} \text { at } 58{ }^{\circ} \mathrm{C} \text {, } \\
1 \text { min at } 72^{\circ} \mathrm{C}\end{array}$ & 290 & $\begin{array}{l}\text { Lb. rhamnosus } \\
\text { Ward and } \\
\text { Timmins [40] }\end{array}$ \\
\hline $\begin{array}{l}\text { 5'-CAG TGG CGC GGT TGA TAT-3' } \\
\text { 5'-TCT GGA TTA CCA AAC ATC AC-3' }\end{array}$ & $\begin{array}{l}5 \text { min at } 94{ }^{\circ} \mathrm{C}, 25 \text { cycles of: } \\
1 \text { min at } 94^{\circ} \mathrm{C}, 1 \text { min at } 58{ }^{\circ} \mathrm{C} \text {, } \\
1 \text { min at } 72^{\circ} \mathrm{C}\end{array}$ & 218 & $\begin{array}{l}\text { Lb. pentosus } \\
\text { Torriani et al. [39] }\end{array}$ \\
\hline $\begin{array}{l}\text { 5'-ATCAAGTACAGTTAGTCTTTATTAG-3' } \\
\text { 5'-ACGATTCAAAGCTAACTGAATCAGT-3' }\end{array}$ & $\begin{array}{l}5 \text { min at } 94{ }^{\circ} \mathrm{C}, 30 \text { cycles of: } \\
1 \text { min at } 94{ }^{\circ} \mathrm{C}, 1 \mathrm{~min} \text { at } 54{ }^{\circ} \mathrm{C} \text {, } \\
1 \mathrm{~min} \text { at } 72{ }^{\circ} \mathrm{C} \text {; final extension } \\
\text { for } 10 \mathrm{~min}\end{array}$ & 941 & $\begin{array}{l}\text { E. faecalis } \\
\text { Dutka-Malen } \\
\text { et al. [19] }\end{array}$ \\
\hline $\begin{array}{l}\text { 5'-TTGAGGCAGACCAGATTGACG-3' } \\
\text { 5'-TATGACAGCGACTCCGATTCC-3' }\end{array}$ & $\begin{array}{l}5 \text { min at } 94{ }^{\circ} \mathrm{C}, 30 \text { cycles of: } \\
1 \text { min at } 94^{\circ} \mathrm{C}, 1 \text { min at } 54{ }^{\circ} \mathrm{C} \text {, } \\
1 \text { min at } 72{ }^{\circ} \mathrm{C} \text {; final extension } \\
\text { for } 10 \text { min }\end{array}$ & 658 & $\begin{array}{l}\text { E. faecium } \\
\text { Cheng et al. [8] }\end{array}$ \\
\hline
\end{tabular}


module from the Taxotron package (Institut Pasteur, Paris, France) for Apple Macintosh computers. Fragment sizes were calculated from migration data using the RestrictoTyper module implementing the Schaffer and Sederoff algorithm [37]. Analysis of the restriction patterns was performed by using different modules from the Taxotron package: distance matrices were generated with the RestrictoTyper module by using the complement of Dice similarity coefficients with $4 \%$ tolerated error; clustering was performed with the Adanson module by the Unweighted Pair Group Method with arithmetic Averages (UPGMA) method based on the Pearson correlation coefficient; the dendrogram tree was constructed using the Dendrograf module.

\subsection{Frequency of isolates}

The frequency of the relative genera of lactic acid bacteria was calculated as the ratio between the sum of the relative frequencies of one genus and the sum of the all relative frequencies of all genera. In turn, the relative frequency of one genus was calculated as the ratio between the count obtained on one enumeration medium at each time of ripening and the number of isolates of that genus on the same medium.

\section{RESULTS}

\subsection{Phenotypic characterization}

Microscopic examination by means of the wet mount indicated that 137 of the isolates were rod shaped, 296 were cocci, 32 were coccobacilli and 3 were tetrads, as a total of 468 Gram positive catalase negative strains.

All rod-shaped cells isolated from the plates incubated at $30{ }^{\circ} \mathrm{C}$ were also able to grow at $15{ }^{\circ} \mathrm{C}$ and $86 \%$ at $45{ }^{\circ} \mathrm{C}$. About $50 \%$ of rod-shaped bacteria isolated at $45{ }^{\circ} \mathrm{C}$ also grew at $15{ }^{\circ} \mathrm{C}$. Of all rodshaped isolates $3 \%$ were facultatively heterofermentative, and these were isolated especially from cheeses in the early stages of ripening. Most of the coccal-shaped bacteria incubated at $30{ }^{\circ} \mathrm{C}$ were able to grow at $45{ }^{\circ} \mathrm{C}, 50 \%$ both at $45{ }^{\circ} \mathrm{C}$ and in presence of $6.5 \%$ of $\mathrm{NaCl}$ and $88 \%$ were able to grow at $10{ }^{\circ} \mathrm{C}$ and $45^{\circ} \mathrm{C}$ and in presence of $6.5 \%$ of $\mathrm{NaCl}$.

\subsection{PCR analysis}

Amplification using primers specific for Lb. casei, Lb. paracasei or Lb. rhamnosus produced products of approximately $290 \mathrm{bp}$, for $\mathrm{Lb}$. plantarum a product of $318 \mathrm{bp}$, for $L b$. curvatus a product of $200 \mathrm{bp}$, and for $L b$. pentosus of $218 \mathrm{bp}$. The PCR products generated with Lactococcus, Enterococcus, Pediococcus, Leuconostoc and Streptococcus specific primers were 570, 733, 439, 175 and 588 bp, respectively.

Table II reports the number of isolates found in each cheese at each ripening stage.

Enterococci were further characterised using species-specific PCR primers for E. faecalis and E. faecium. Twelve isolates, representing 221 of the Enterococcus isolates, reacted positively with the E. faecalis species-specific primers; the remaining 209 isolates reacted with the E. faecium species-specific primers. These data indicate that E. faecium is, among the total of isolates, the dominant species of Enterococcus in Pecorino Siciliano cheese throughout ripening. All genotypes obtained by PCR analysis confirmed the phenotypes identified by phenotypic tests, excepted for some lactococci. Indeed, $28 \%$ of isolates that resulted to belonged to Enterococcus genus by phenotypic tests resulted, instead, Lactococcus. 
Table II. Number of isolates found in each cheese at each ripening.

\begin{tabular}{lcccc}
\hline & \multicolumn{3}{c}{ Days of ripening } \\
\hline & $1 \mathrm{~d}$ & $30 \mathrm{~d}$ & $90 \mathrm{~d}$ & Total \\
\hline Lactococci & 48 & 8 & 3 & 59 \\
Streptococci & - & - & 4 & 4 \\
Enterococci & 60 & 76 & 85 & 221 \\
Leuconostoc & 22 & 4 & 5 & 34 \\
Pediococci & - & - & 1 & 1 \\
Lb. plantarum & 12 & 30 & 16 & 58 \\
Lb. pentosus & 2 & & - & 2 \\
Lb. rhamnosus & 6 & 3 & - & 9 \\
Lb. curvatus & 3 & 1 & - & 4 \\
Lb. paracasei & 15 & 14 & 50 & 79 \\
\hline
\end{tabular}

These isolates could be defined as "atypical" lactococci, displaying a fairly growing in the presence of $6.5 \%$ of $\mathrm{NaCl}$ and at $45{ }^{\circ} \mathrm{C}$.

\subsection{Estimation of the number of strains of lactic acid bacteria present in Pecorino Siciliano cheese during ripening by Pulsed-field gel electrophoresis (PFGE)}

Analysis by pulsed-field gel electrophoresis (PFGE) of the chromosomal macrorestriction patterns generated by ApaI or AscI digestion of total bacterial DNA allowed 468 lactic acid bacterial isolates to be divided into several groups, each consisting of isolates showing the same band pattern and thus considered to be identical isolates. To aid analysis of the data, a Pearson's coefficient of similarity between patterns was computed and used to construct a dendrogram for the 468 isolates (Figs. 1 and 2, electronic-material only $^{1}$ ). The rod-shaped isolates, identified

\footnotetext{
${ }^{1}$ Available at: http://dx.doi.org/10.1051/dst: 2008009.
}

as members of the genus Lactobacillus were digested by AscI, while the coccus isolates, identified as members of the genera Lactococcus, Enterococcus, Leuconostoc, Pediococcus, Streptococcus were digested with ApaI. Isolates of Lactobacillus or coccus with a Pearson's coefficient of similarity of $>80 \%$ or $>70 \%$ respectively, were considered to be identical and were thus grouped within an individual cluster on the dendrogram.

The Lactobacillus group could be subgrouped into a total of 17 clusters at the $80 \%$ similarity level, each containing one or more isolates. The Lactobacillus isolates identified formed 17 distinct clusters, numbered 1-17 (Fig. 1). Three of the clusters, numbers 1,3 and 6 , contained $74 \%$ of the isolates. Eleven of the clusters belonged to $L b$. plantarum, 3 to $L b$. paracasei, 1 to Lb. pentosus, 1 to Lb. curvatus, 1 to Lb. rhamnosus.

The coccus group could be divided in 68 clusters at $70 \%$ similarity level (Fig. 2), each containing one or more isolates. Only few PFGE patterns of enterococci were common among the samples at different stages of ripening. Indeed, some of the PFGE patterns were unique, found only in a particular stage of ripening, whereas 
other were found in cheeses throughout ripening. The E. faecalis identified formed three separate clusters numbered 34,45 , 54. In addition Figures 1 and 2 show that a limited number of biotypes were dominant (PFGE patterns numbered 1 and 3 for lactobacilli; PFGE patterns 1, 27, 30 and 52 for coccal-shaped cells), while most of the strains were isolated only once.

Number of isolates in each species/genus (lactobacilli, coccus groups respectively) and number of pulsotypes by species/genus are summarised in Figures 1 and 2 respectively.

Finally, the frequency of the respective genera of lactic acid bacteria were calculated to evaluate the relative predominance in the cheese during ripening. The frequency calculated after $1 \mathrm{~d}, 30 \mathrm{~d}$ of ripening (data not shown) revealed the predominance of enterococci and lactococci for all cheeses. The frequency calculated at $90 \mathrm{~d}$ of ripening (data not shown) revealed the predominance of enterococci and $L b$. paracasei for all cheeses.

\section{DISCUSSION}

In recent years, there has been a growing interest in genotypic and phenotypic studies on wild isolates from artisanal cheeses produced mainly without the addition of a starter cultures $[1,10,11,17,24$, $35,38]$. Increasing information on the natural microbial population present in dairy products can help to prevent the loss of microbial biodiversity in typical foods and consequently the loss of a wide range of cheeses produced by different methods whose typical features depend on local and regional traditions and on the indigenous microbial population present in raw milk and selected due to the cheese-making environment.

In this study, two molecular techniques, PCR and PFGE were used to identify 468 Gram-positive, catalase-negative iso- lates from 6 Pecorino Siciliano cheeses at different stages of ripening.

The bacterial flora was dominated by coccal-shaped isolates during the early stage of ripening, while in the 90 days old cheeses the lactobacilli increased also. Of the 52 clusters of enterococci found by combining PCR and PFGE, only a few biotypes were common among the cheeses at different stages of ripening. The variability of enterococci isolated from Pecorino Siciliano cheese samples confirm the previous studies on traditional cheeses $[6,10$, 30]. In cheese, particularly in traditional raw milk cheeses, enterococci are involved in the primary fermentation activity, but they also form part of the secondary nonstarter lactic acid bacteria (NSLAB) involved in the ripening process and in aroma development $[10,26]$. These beneficial effects have been attributed to their proteolytic and lipolytic activities [7, 18,36,41].

Strains identified as Lactococcus were dominant during the early stage of manufacture in the $1 \mathrm{~d}$ old cheese. About $80 \%$ of lactococci were isolated in the $1 \mathrm{~d}$ and $30 \mathrm{~d}$ cheeses. This result suggests the hypothesis that an early autolysis of lactococci can occur, and the releasing of their enzymes into the curd can contribute to the acceleration of ripening and is likely to influence the ripening properties of these cheeses [25] or they could also survive as VNC (viable but not cultivable) or die without lysis. In previous studies, strains of lactococci were found to be the dominant bacteria in Pecorino Siciliano cheese in the first stage of ripening [35]. Indeed, $28 \%$ of the lactococcal isolates (identified by PCR) in this study displayed "atypical" phenotype of growing both in the presence of $6.5 \% \mathrm{NaCl}$ and at $45^{\circ} \mathrm{C}$, and $85 \%$ grew at $45{ }^{\circ} \mathrm{C}$. Other authors found lactococci showing an atypical phenotype from raw milk and from artisanal cheeses $[12,23]$.

The strains dominating the first stages are not necessarily present in the later phases of ripening. Indeed, many of the 
strains of $L b$. plantarum were abundant during the early stage of ripening (data not shown), then decreasing during ripening, whereas the number of $L b$. paracasei increased or remained constant in all six batches of $90 \mathrm{~d}$-old cheese. Strains of $L b$. curvatus were found only in the early stages of ripening. NSLAB constitute complex microbial associations that are characterized by the occurrence of various species and many biotypes as a result of a number of selective conditions persisting during the manufacturing process and different ecological niches [29]. The NSLAB community is composed mostly of mesophilic lactobacilli such as Lb. paracasei, Lb. plantarum, and Lb. curvatus [2,25]. Nevertheless, pediococci, and leuconostoc could also be present $[5,22,27]$.

During the ripening period the number of lactobacilli was increasing most probably because of their higher ability to grow under the low pH conditions [6]. Mesophilic lactobacilli are important in the maturation of cheeses as they are able to ferment citrate and could be involved in proteolysis as well as in other enzymatic processes that occurred during cheese ripening [14]. PFGE analysis revealed a wide biodiversity of the complex environment of Pecorino Siciliano cheese. During the ripening different PFGE patterns were found for the same microbial species, revealing the presence of different strains of E. faecium, E. faecalis, Lb. plantarum, Lb. paracase i and Leuconostoc.

The results of this study enabled the dominant biotypes in Pecorino Siciliano cheese to be defined at each period of ripening. It was found that the strains that dominated the first stages of ripening were not necessarily predominant in the later periods and vice versa. In addition, a limited number of biotypes were dominant while most of the strains were isolated only once. Strains can be accidentally present and contribute to cheese organoleptic properties. Those strains which are more sus- ceptible or resistant to the adverse conditions occurring during ripening could be of interest when autochthonous strains selected from the natural environment are used in the dairy industry. Moreover, the strains isolated in this study may be used as a basis for comparing, in further studies, Pecorino Siciliano cheeses made with the addition of different microbial associations. A complexity of the natural microbial population was found in traditional Pecorino Siciliano cheese during the overall period of ripening and this aspect underlines the importance of the protection of the wild microbial population associated with the production of traditional cheeses.

Further investigations into strain variability should focus on interesting technological characteristics such as their capacity to grow in milk, autolyse in cheese and contribute to proteolysis, lipolysis and amino acid catabolism.

\section{REFERENCES}

[1] Baruzzi F., Morea M., Matarante A., Cocconcelli P.S., Changes in the Lactobacillus community during Ricotta forte cheese natural fermentation, J. Appl. Microbiol. 89 (2000) 807-814.

[2] Beresford T.P., Fitzsimons N.A., Brennan N.L., Cogan T.M., Recent advances in cheese microbiology, Int. Dairy J. 11 (2001) 259-274.

[3] Berthier F., Ehrlich S.D., Rapid species identification within two groups of closely related Lactobacillus using PCR primers that target the $16 \mathrm{~S} / 23 \mathrm{~S}$ rRNA spacer region, FEMS Microbiol. Lett. 161 (1998) 97-106.

[4] Brennan N.M., Ward A.C., Beresford T.P., Fox P.F., Goodfellow M., Cogan T.M., Biodiversity of the bacterial flora on the surface of a smear cheese, Appl. Environ. Microbiol. 68 (2002) 820-830.

[5] Callon C., Millet L., Montel M.C., Diversity of lactic acid bacteria isolated from AOC Salers cheese, J. Dairy Res. 71 (2004) 231244.

[6] Caridi A., Micari P., Caparra P., Cufari A., Sarullo V., Ripening and seasonal changes in microbial groups and in physico-chemical 
properties of the ewes' cheese Pecorino del Poro, Int. Dairy J. 13 (2003) 191-200.

[7] Centeno J.A., Menendez S., Hermida M.A., Rodriguez-Otero J.L., Effects of the addition of Enterococcus faecalis in Cebreiro cheese manufacture, Int. J. Food Microbiol. 48 (1999) 97-111.

[8] Cheng S., McCleskey F.K., Gress M.J., Petroziello J.M., Liu R., Namdari H., Beninga K., Salmen A., del Vecchio V.G., A PCR assay for identification of Enterococcus faecium, J. Clin. Microbiol. 35 (1997) 12481250.

[9] Coakley M., Ross R.P., Donnelly D., Application of the polymerase chain reaction to the rapid analysis of brewery yeast strains, J. Inst. Brew. 102 (1996) 349-354.

[10] Coeuret V., Dubernet S., Bernardeau M., Gueguen M., Vernoux J.P., Isolation, characterisation and identification of lactobacilli focusing mainly on cheeses and other dairy products, Lait 83 (2003) 269-306.

[11] Cogan T.M., Barbosa M., Beuvier E., Bianchi-Salvadori B., Cocconcelli P.S., Ferenandes I., Gomez J., Gomez R., Kalantzopoulos G., Ledda A., Medina M., Rea M.C., Rodriguez E., Characterisation of the lactic acid bacteria in artisanal dairy products, J. Dairy Res. 64 (1997) 409-421.

[12] Coppola S., Blaiotta G., Ercolini D., Moschetti G., Molecular evaluation of microbial diversity occurring in different types of Mozzarella cheese, J. Appl. Microbiol. 90 (2001) 414-420.

[13] Corroler D., Mangin I., Desmasures N., Gueguen M., An ecological study of lactococci isolated from raw milk in the Camembert cheese Registred Designation of Origin area, Appl. Environ. Microbiol. 64 (1998) 4729-4735.

[14] Crow V., Curry B., Hayes M., The ecology of non-starter lactic acid bacteria (NSLAB) and their use as adjuncts in New Zealand Cheddar, Int. Dairy J. 11 (2001) 275-283.

[15] Deasy B.M., Methods for the rapid identification of dairy lactic acid bacteria, Ph.D. thesis, National University of Ireland, Cork, 2000.

[16] Deasy B.M., Rea M.C., Fitzgerald G.F., Cogan T.M., Beresford T.P., A rapid PCR method to distinguish between Lactococcus and Enterococcus, Syst. Appl. Microbiol. 23 (2000) 510-522.

[17] Desmasures N., Mangin I., Corroler D., Guéguen M., Characterization of lactococci isolated from milk produced in the
Camembert region of Normandy, J. Appl. Microbiol. 85 (1998) 999-1005.

[18] Durlu-Ozkaya F., Xanthopoulos V., Tunail N., Litopoulou-Tzanetaki E., Technologically important properties of lactic acid bacteria isolates from Beyaz cheese made from raw ewes' milk, J. Appl. Microbiol. 91 (2001) 861-870.

[19] Dutka-Malen S., Evers S., Courvalin P., Detection of glycopeptide resistance genotypes and identification to the species level of clinically relevant enterococci by PCR, J. Clin. Microbiol. 33 (1995) 24-27 (Erratum, 33:1434).

[20] Ercolini D., Blaiotta G., Moschetti G., Coppola S., Evaluation of PCR-DGGE analysis for molecular typing of cheeses, Ann. Microbiol. 52 (2002) 81-87.

[21] Farber J.M., An introduction to the hows and whys of molecular typing, J. Food Prot. 59 (1996) 1091-1101.

[22] Fitzsimons A.N., Cogan T.M., Condon S., Beresford T., Phenotypic and genotypic characterization of non-starter lactic acid bacteria in mature cheddar cheese, Appl. Environ. Microbiol. 65 (1999) 3418-3426.

[23] Fortina M.G., Ricci G., Acquati A., Zeppa G., Gandini A., Manachini P.L., Genetic characterization of some lactic acid bacteria occurring in an artisanal protected denomination origin (PDO) Italian cheese, the Toma Piemontese, Food Microbiol. 20 (2003) 397404.

[24] Madrau M.A., Mangia N.P., Murgia M.A., Sanna M.G., Garau G., Leccis L., Caredda M., Deiana P., Employment of autochthonous microflora in Pecorino Sardo cheese manufacturing and evolution of physicochemical parameters during ripening, Int. Dairy J. 16 (2006) 876-885.

[25] Mannu L., Paba A., Genetic diversity of lactococci and enterococci isolated from homemade Pecorino Sardo ewes' milk cheese, J. Appl. Microbiol. 92 (2002) 55-62.

[26] Mannu L., Paba A., Pes M., Scintu M.F., Genotypic and phenotypic heterogeneity among lactococci isolated from traditional Pecorino Sardo cheese, J. Appl. Microbiol. 89 (2000) 191-197.

[27] Manolopoulou E., Sarantinopoulos P., Zoidou E., Aktypis A., Moschopoulou E., Kandarakis I.G., Anifantakis E.M., Evolution of microbial populations during traditional Feta cheese manufacture and ripening, Int. J. Food Microbiol. 82 (2003) 153-161. 
[28] McCartney A.L., Application of molecular biological methods for studying probiotics and the gut flora, Brit. J. Nutr. 88 (2002) 2938.

[29] McSweeney P.L.H., Fox P.F., Lucey J.A., Jordan K.N., Cogan T.M., Contribution of the indigenous microflora to the maturation of Cheddar cheese, Int. Dairy J. 3 (1993) 613-634.

[30] Medina R., Katz M., Gonzalez S., Oliver G., Characterization of the lactic acid bacteria in ewe's milk and cheese from northwest Argentina, J. Food Prot. 64 (2001) 559-563.

[31] Nissen H., Holck A., Dainty R.H., Identification of Carnobacterium spp. and Leuconostoc spp. in meat by genusspecific 16S rRNA probes, Lett. Appl. Microbiol. 19 (1994) 165-168.

[32] Psoni L., Kotzamanidis C., Yiangou M., Tzanetakis N., Litopoulou-Tzanetaki E., Genotypic and phenotypic diversity of Lactococcus lactis isolates from Batzos, a Greek PDO raw goat milk cheese, Int. J. Food Microbiol. 114 (2007) 211-220.

[33] Quere F., Deschamps A., Urdaci M.C., DNA probe and PCR-specific reaction for Lactobacillus plantarum, J. Appl. Microbiol. 82 (1997) 783-790.

[34] Randazzo C.L., Torriani S., Akkermans A.D.L., De Vos W.M., Vaughan E.E., Diversity, dynamics, and activity of bacterial communities during production of an artisanal Sicilian cheese as evaluated by $16 \mathrm{~S}$ rRNA analysis, Appl. Environ. Microbiol. 68 (2002) 1882-1892.

[35] Randazzo C.L., Vaughan E.E., Caggia C., Artisanal and experimental Pecorino Siciliano cheese: Microbial dynamics during manufacture assessed by culturing and PCR-DGGE analyses, Int. J. Food Microbiol. 109 (2006) 1-8.

[36] Sarantinopoulos P., Kalantzopoulos G., Tsakalidou E., Effect of Enterococcus faecium on microbiological, physicochemical and sensory characteristics of Greek Feta cheese, Int. J. Food Microbiol. 76 (2002) 93-105.

[37] Schaffer H.E., Sederoff R.R., Improved estimation of DNA fragment lengths from Agarose gels, Anal. Biochem. 115 (1981) 113-122.

[38] Suzzi G., Caruso M., Gardini F., Lombardi A., Vannini L., Guerzoni M.E., Andrighetto C., Lanorte M.T., A survey of the enterococci isolated from an artisanal Italian goat's cheese (semicotto caprino), J. Appl. Microbiol. 89 (2000) 267-274.

[39] Torriani S., Felis G.E., Dellaglio F., Differentiation of Lactobacillus plantarum, Lactobacillus pentosus and Lactobacillus paraplantarum by recA Gene Sequence Analysis and Multiplex PCR assay with recA gene - derived primers, Appl. Environ. Microbiol. 67 (2001) 3450-3454.

[40] Ward L.J.H., Timmins M.J., Differentiation of Lactobacillus casei, Lactobacillus paracasei and Lactobacillus rhamnosus by polymerase chain reaction, Lett. Appl. Microbiol. 29 (1999) 90-92.

[41] Wessels D., Jooste P.J., Mostert J.F., Technologically important characteristics of Enterococcus isolates from milk and dairy products, Int. J. Food Microbiol. 10 (1990) 349-352. 